Article

\title{
Effect of Soil Type: Qualitative and Quantitative Analysis of Phytochemicals in Some Browse Species Leaves Found in Savannah Biome of South Africa
}

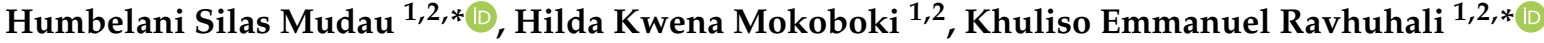 \\ and Zimbili Mkhize ${ }^{3}$
}

check for updates

Citation: Mudau, H.S.; Mokoboki, H.K.; Ravhuhali, K.E.; Mkhize, Z. Effect of Soil Type: Qualitative and Quantitative Analysis of Phytochemicals in Some Browse Species Leaves Found in Savannah Biome of South Africa. Molecules 2022, 27, 1462. https://doi.org/ $10.3390 /$ molecules 27051462

Academic Editor: Francesco Cacciola

Received: 21 January 2022

Accepted: 19 February 2022

Published: 22 February 2022

Publisher's Note: MDPI stays neutral with regard to jurisdictional claims in published maps and institutional affiliations.

Copyright: (C) 2022 by the authors. Licensee MDPI, Basel, Switzerland. This article is an open access article distributed under the terms and conditions of the Creative Commons Attribution (CC BY) license (https:// creativecommons.org/licenses/by/ $4.0 /)$.
1 Department of Animal Science, School of Agricultural Sciences, Faculty of Natural and Agricultural Sciences, North-West University, Mmabatho 2735, South Africa; hilda.mokoboki@nwu.ac.za

2 Food Security and Safety Niche Area, Faculty of Natural and Agricultural Sciences, North-West University, Mmabatho 2735, South Africa

3 Department of Chemistry, School of Chemical and Physical Sciences, Faculty of Natural and Agricultural Sciences, North-West University, Mmabatho 2735, South Africa; zimbili.mkhize@nwu.ac.za

* Correspondence: mudausilas@gmail.com (H.S.M.); ravhuhalike@gmail.com (K.E.R.)
Abstract: In semi-arid regions, browse plant species are used as feed and for medicinal purposes for both animals and humans. The limitation of the utilization of these species to medicinal purposes or as feed for livestock is a lack of knowledge on the concentration level of phytochemicals and other bioactive compounds found in these plants. The study sought to assay the qualitative and quantitative bioactive constituents of some browse species found in the savannah biome of South Africa, viz. Adansonia digitate, Androstachys johnsonii, Balanites maughamii, Berchemia discolor, Berchemia zeyheri, Bridelia mollis hutch, Carissa edulis, Catha edulis, Colophospermum mopane, Combretum Imberbe, Combretum molle, Combretum collinum, Dalbergia melanoxylon, Dichrostachys cinerea, Diospros lycioides, Diospyros mespiliformis, Euclea divinorum, Flueggea virosa, Grewia flava, Grewia flavescens, Grewia monticola, Grewia occidentalis, Melia azedarach, Peltophorum africanum, Prosopis velutina, Pseudolachnostylis maprouneifolia, Pterocarpus rotundifolius, Schinus molle, Schotia brachypetala, Sclerocarya birrea, Searsia lancea, Searsia leptodictya, Searsia pyroides, Senegalia caffra, Senegalia galpinii, Senegalia mellifera, Senegalia nigrescens, Senegalia polyacantha, Strychnos madagascariensis, Terminalia sericea, Trichilia emetic, Vachellia erioloba, Vachellia hebeclada, Vachellia karroo, Vachellia nilotica, Vachellia nilotica subsp. Kraussiana, Vachellia rechmanniana, Vachellia robusta, Vachellia tortilis, Vachellia tortilis subsp. raddiana, Vangueria infausta, and Ziziphus mucronata. These browse species' leaf samples were harvested from two provinces (Limpopo and North-West) of South Africa. The Limpopo province soil type was Glenrosa, Mispah, and Lithosols (GM-L), and the soil types in the North-West Province were Aeolian Kalahari Sand, Clovelly, and Hutton (AKS-CH). The harvested browse samples were air dried at room temperature for about seven days and ground for analysis. The methanol and distilled water extracts of the browse species leaves showed the presence of common phytoconstituents, including saponins, flavonoids, tannins, phenols, cardio glycosides, terpenoids, and phlobatannins, as major active compounds in browse species leaves. In the quantitative analysis, phytochemical compounds, such as soluble phenols, insoluble tannins, and condensed tannins, were quantified for common species found in both sites. Two-way ANOVA and multivariate analysis were used to test soil type and species effect on soluble phenols, insoluble tannins, and condensed tannins of woody species. Dichrostachys cinerea $(0.1011 \%$ DM) in GM-L soil type and Z. mucronata (0.1009\% DM) in AKS-CH soil type showed the highest $(p<0.05)$ concentration of soluble phenols. In AKS-CH soil type, D. cinerea $(0.0453 \% \mathrm{DM}) \mathrm{had}$ the highest insoluble tannins concentration, while $V$. hebeclada had the lowest $(0.0064 \% \mathrm{DM})$ insoluble tannins content. Vacchelia hebeclada had lower $(p<0.05)$ condensed tannins concentration levels than all other browse plants in both soil types. Under multivariate analysis tests, there was a significant effect $(p<0.001)$ of soil type, species, and soil type $\mathrm{x}$ species interaction on soluble phenols, insoluble tannins, and condensed tannins of woody species. In this study, most of the woody species found in GM-L soil type showed a lower amount of tannins than those harvested in AKS-CH soil type. There is a need to identify the amount of unquantified phytochemicals contained in these browse species 
and valorize the high-bioactive-compound browse species to enhance and maximize browsing of these browse species for animal production.

Keywords: phytochemical; browse species; quantitative screening; qualitative screening; livestock; bioactive compounds

\section{Introduction}

Savannah woody species play an important role as the cheapest protein source for livestock in semi-arid regions [1]. Some of these plants are deciduous and semi-succulent. They can retain green leaves in certain seasons of the year, making them advantageous in responding to feed shortages during dry seasons, when the herbaceous species and other annual grasses wilt $[2,3]$. These plants' contributions to multi-purpose tasks (protein and medicinal sources) have been documented [4-6].

The chemical composition of browse species varies with plant species, growth, plant parts, soil type, temperature, altitude, light, and other anthropogenic factors, such as herbivory [7-10]. Some of these woody species contain plant secondary metabolites (phytochemicals) which are anti-nutritional elements, which may negatively affect an animal's health and nutrition [11,12]. A large number of bioactive compounds, including phenols, flavonoids, tannins, coumarin, lignin, terpenes, saponins, phlobatannins, and glycosides, are usually scattered in plant species [13]. Mazid et al. [14] pointed out that phenolic compounds are known to be abundant plant secondary metabolites in browse species which can contribute up to half of their organic matter.

Furthermore, Liu et al. [15] highlighted that phenolic compounds, structurally, are made up of aromatic benzene rings with more than one hydroxyl group, arranged from lower to higher polymerization levels. According to Mueller-Harvey [16], tannins, flavonoids, and phenolic acids are phenolic compounds which are abundantly constituted in savannah woody species, and they play a significant role in animal nutrition, health, and performance [17]. Flavonoids are a group of secondary metabolites found in plants with a lower molecular weight, and they are constituted with major classes, such as flavonols, flavones, and isoflavones.

Plant secondary metabolites (phytochemicals) offer important pharmacological and biological properties, including hypoglycemic, anti-inflammatory, antioxidant, anti-bacterial, and anti-carcinogenic properties, which can fight against oxidative cell damage [18-20]. These bioactive compounds are also essential sources for proper plant growth and defensive mechanisms against infection and plant cell damage. Salem et al. [21] indicated that the isolation and identification of browse plant phytochemicals have long been a difficult challenge for researchers. Different plant species can have variation in secondary metabolites produced through biosynthesis [22]. Though there are numerous research studies that have been conducted worldwide with special focus on phytochemical medicinal plants [23-27], little scientific validation has been carried out for browse species phytochemicals found in most semi-arid areas of South Africa. There is a need to perform screening of phytochemicals in order to establish the concentration levels of these browse species. This is a valuable step to serve as a guiding tool to identify and manipulate those browse species that might be toxic to ruminants due to high concentration of certain bioactive compounds. Therefore, the current study was designed to evaluate the existence of phytochemical components and assess the qualitative and quantitative aspects of phytochemicals present in browse species extracts. The study hypothesized that there was variation in the qualitative and quantitative aspects of phytochemicals present in browse plant species, given the therapeutic value of these widely accessible browse plant species. Hopefully, the study will contribute to the improvement of livestock production in savannah areas of South Africa. 


\section{Results}

\subsection{Preliminary Qualitative Phytochemical Analysis}

Results of phytochemical screenings of browse species found in GM-L soil type are shown in Table 1. Phytochemical compounds such as saponins, flavonoids, tannin, phenols, glycosides, terpenoids, and phlobatannins were screened and observed in methanol and distilled water extracts. Phlobatannins were found to be absent in distilled water extracts for all browse species harvested in both soil types. Terpenoids were present in both methanol and distilled water extracts, except for S. galpinii, which was found to be negative in the distilled water extract. Negative results for tannins and phenols were found in most browse leaves from distilled water extracts. Vachellia hebeclada showed negative results for phlobatannins, glycosides, phenols, and tannins in both methanol and distilled water extracts. Saponins and flavonoids were present in all browse species from distilled water extracts, except for $C$. edulis, $T$. sericea, and $V$. tortilis subsp. taddiana.

Table 1. Qualitative phytochemical screening using methanol and distilled water on woody species found in GM-L soil type.

\begin{tabular}{|c|c|c|c|c|c|c|c|c|c|c|c|c|c|c|}
\hline \multirow{3}{*}{ Species } & \multicolumn{14}{|c|}{ Phytochemical Group } \\
\hline & \multicolumn{2}{|c|}{ Saponins } & \multicolumn{2}{|c|}{ Flavonoids } & \multicolumn{2}{|c|}{ Tannins } & \multicolumn{2}{|c|}{ Phenols } & \multicolumn{2}{|c|}{ Glycosides } & \multicolumn{2}{|c|}{ Terpenoids } & \multicolumn{2}{|c|}{ Phlobatannins } \\
\hline & $\mathbf{W}$ & $\mathbf{M}$ & $\mathbf{W}$ & $\mathbf{M}$ & $\mathbf{W}$ & $\mathbf{M}$ & $\mathbf{W}$ & $\mathbf{M}$ & $\mathbf{W}$ & $\mathbf{M}$ & $\mathbf{W}$ & $\mathbf{M}$ & $\mathbf{W}$ & $\mathbf{M}$ \\
\hline A. digitata & ++ & + & + & - & - & + & - & - & + & +++ & +++ & +++ & - & - \\
\hline A. johnsonii & ++ & +++ & +++ & +++ & +++ & +++ & +++ & +++ & ++ & +++ & ++ & +++ & - & +++ \\
\hline B. maughamii & +++ & +++ & + & - & + & + & - & + & + & + & + & ++ & - & - \\
\hline B. discolour & +++ & + & +++ & +++ & ++ & ++ & - & + & ++ & ++ & +++ & +++ & - & - \\
\hline B. zeyheri & ++ & +++ & +++ & ++ & +++ & +++ & +++ & +++ & + & + & + & +++ & - & - \\
\hline B. mollis $H$ & +++ & +++ & ++ & ++ & +++ & +++ & +++ & +++ & +++ & +++ & ++ & +++ & - & +++ \\
\hline Catha edulis & - & - & + & + & + & - & + & + & + & + & + & + & - & - \\
\hline C. mopane & +++ & ++ & ++ & ++ & + & - & + & ++ & +++ & +++ & +++ & +++ & - & +++ \\
\hline C. Imberbe & + & + & +++ & +++ & +++ & +++ & +++ & +++ & + & ++ & + & +++ & - & + \\
\hline C. molle & +++ & +++ & +++ & +++ & +++ & +++ & +++ & +++ & ++ & +++ & ++ & ++ & - & ++ \\
\hline C. collinum & ++ & ++ & +++ & +++ & ++ & +++ & +++ & ++ & ++ & ++ & +++ & +++ & - & ++ \\
\hline D. melanoxylon & + & + & + & + & + & ++ & - & ++ & + & ++ & + & +++ & - & - \\
\hline D. cinerea & +++ & +++ & +++ & +++ & ++ & +++ & ++ & +++ & +++ & +++ & +++ & +++ & - & +++ \\
\hline D. mespiliformis & +++ & +++ & + & + & ++ & +++ & +++ & +++ & ++ & +++ & ++ & +++ & - & + \\
\hline E. divinorum & + & +++ & +++ & ++ & ++ & +++ & ++ & +++ & + & +++ & ++ & +++ & - & + \\
\hline G. flava & + & - & - & - & - & + & - & - & - & ++ & + & +++ & - & - \\
\hline G. flavescens & +++ & + & ++ & ++ & + & ++ & + & ++ & + & ++ & +++ & +++ & - & +++ \\
\hline G. monticola & ++ & + & ++ & ++ & - & - & - & - & ++ & + & + & ++ & - & - \\
\hline G. occidentalis & ++ & +++ & +++ & +++ & ++ & ++ & ++ & +++ & + & + & + & + & - & ++ \\
\hline M. azedarach & +++ & +++ & ++ & +++ & - & - & - & - & - & - & ++ & + & - & - \\
\hline P. africanum & ++ & +++ & +++ & +++ & +++ & +++ & ++ & +++ & + & ++ & ++ & +++ & - & ++ \\
\hline P. maprouneifolia & ++ & - & ++ & + & - & ++ & - & ++ & ++ & ++ & + & +++ & - & + \\
\hline S. molle & +++ & + & - & + & - & - & - & - & - & + & +++ & +++ & - & - \\
\hline S. brachypetala & +++ & +++ & + & + & ++ & ++ & +++ & +++ & +++ & +++ & + & ++ & - & + \\
\hline S. birrea & ++ & +++ & ++ & + & +++ & +++ & ++ & +++ & + & +++ & + & +++ & - & +++ \\
\hline S. leptodictya & ++ & + & - & + & - & - & - & - & + & - & +++ & +++ & - & - \\
\hline S. caffra & +++ & ++ & + & ++ & - & ++ & - & + & +++ & ++ & +++ & +++ & - & - \\
\hline S. galpinii & +++ & - & + & - & - & + & + & + & ++ & ++ & - & ++ & - & - \\
\hline S. nigrescens & +++ & +++ & ++ & + & +++ & +++ & + & ++ & ++ & ++ & ++ & +++ & - & +++ \\
\hline S. polyacantha & +++ & +++ & + & + & - & ++ & - & + & + & + & + & ++ & - & +++ \\
\hline S. madagascariensis & +++ & + & +++ & +++ & +++ & ++ & +++ & ++ & ++ & +++ & +++ & +++ & - & - \\
\hline T. sericea & - & ++ & ++ & ++ & +++ & +++ & +++ & +++ & +++ & + & +++ & +++ & - & +++ \\
\hline T. emetic & +++ & - & ++ & + & ++ & ++ & + & + & + & ++ & ++ & +++ & - & + \\
\hline
\end{tabular}


Table 1. Cont.

\begin{tabular}{|c|c|c|c|c|c|c|c|c|c|c|c|c|c|c|}
\hline \multirow{3}{*}{ Species } & \multicolumn{14}{|c|}{ Phytochemical Group } \\
\hline & \multicolumn{2}{|c|}{ Saponins } & \multicolumn{2}{|c|}{ Flavonoids } & \multicolumn{2}{|c|}{ Tannins } & \multicolumn{2}{|c|}{ Phenols } & \multicolumn{2}{|c|}{ Glycosides } & \multicolumn{2}{|c|}{ Terpenoids } & \multicolumn{2}{|c|}{ Phlobatannins } \\
\hline & $\mathbf{W}$ & $\mathbf{M}$ & $\mathbf{W}$ & $\mathbf{M}$ & $\mathbf{W}$ & $\mathbf{M}$ & $\mathbf{W}$ & $\mathbf{M}$ & $\mathbf{W}$ & $\mathbf{M}$ & $\mathbf{W}$ & $\mathbf{M}$ & $\mathbf{W}$ & $\mathbf{M}$ \\
\hline V. hebeclada & +++ & + & - & + & - & - & - & - & - & - & ++ & +++ & - & - \\
\hline V. karroo & +++ & ++ & - & ++ & - & ++ & - & + & - & ++ & +++ & +++ & - & + \\
\hline V. nilotica & +++ & + & +++ & +++ & +++ & ++ & ++ & ++ & +++ & +++ & +++ & +++ & - & ++ \\
\hline $\begin{array}{l}\text { V. nilotica subsp. } \\
\text { Kraussiana }\end{array}$ & + & +++ & +++ & +++ & +++ & +++ & + & ++ & ++ & +++ & +++ & +++ & - & + \\
\hline V. rechmanniana & +++ & +++ & ++ & ++ & ++ & +++ & ++ & +++ & ++ & ++ & +++ & +++ & - & +++ \\
\hline V. tortilis & +++ & ++ & + & ++ & + & ++ & ++ & ++ & + & + & + & ++ & - & ++ \\
\hline $\begin{array}{l}\text { V. tortilis subsp. } \\
\text { raddiana }\end{array}$ & - & + & + & ++ & ++ & ++ & ++ & ++ & ++ & +++ & +++ & +++ & - & + \\
\hline V. infausta & +++ & ++ & ++ & ++ & ++ & + & ++ & + & + & + & +++ & ++ & - & - \\
\hline Z. mucronata & ++ & + & + & + & - & ++ & ++ & ++ & + & + & + & +++ & - & + \\
\hline
\end{tabular}

+++: highly present; ++: moderately present; +: low; -: absent; M: methanol; W: water extract; GM-L: Glenrosa, Mispah, and Lithosols soil types.

In Table 2, for AKS-CH soil type, terpenoids were present in both methanol and distilled water extracts, except only for $V$. nilotica subsp. Kraussiana, which were absent in the water extract. Saponins were not present only in S. molle when using both methanol and distilled water extracts. Senegalia galpinii and $V$. hebeclada were found negative in tannins, phenols, glycoside, and phlobatannins in both methanol and distilled water extracts. Flavonoid, saponins, tannins, and phenols were present in most browse species from methanol extracts.

Table 2. Qualitative phytochemical screening using methanol and water on woody species found in AKS-CH soil type.

\begin{tabular}{|c|c|c|c|c|c|c|c|c|c|c|c|c|c|c|}
\hline \multirow{3}{*}{ Species } & \multicolumn{14}{|c|}{ Phytochemical Group } \\
\hline & \multicolumn{2}{|c|}{ Saponins } & \multicolumn{2}{|c|}{ Flavonoids } & \multicolumn{2}{|c|}{ Tannins } & \multicolumn{2}{|c|}{ Phenols } & \multicolumn{2}{|c|}{ Glycosides } & \multicolumn{2}{|c|}{ Terpenoids } & \multicolumn{2}{|c|}{ Phlobatannins } \\
\hline & $\mathbf{W}$ & $\mathbf{M}$ & $\mathbf{W}$ & $\mathbf{M}$ & $\mathbf{W}$ & $\mathbf{M}$ & $\mathbf{W}$ & $\mathbf{M}$ & $\mathbf{W}$ & $\mathbf{M}$ & $\mathbf{W}$ & $\mathbf{M}$ & $\mathbf{W}$ & $\mathbf{M}$ \\
\hline D. cinerea & +++ & + & - & + & +++ & +++ & +++ & +++ & +++ & +++ & +++ & +++ & - & +++ \\
\hline D. lycioides & +++ & +++ & - & +++ & - & - & - & +++ & + & + & +++ & +++ & - & - \\
\hline G. flava & +++ & ++ & - & ++ & - & + & + & - & + & +++ & + & ++ & - & - \\
\hline M. azedarach & +++ & ++ & ++ & ++ & +++ & ++ & +++ & +++ & + & + & ++ & +++ & - & + \\
\hline P. africanum & + & +++ & - & +++ & + & ++ & + & + & + & + & + & + & - & - \\
\hline P. velutina & +++ & ++ & + & ++ & - & ++ & - & + & +++ & - & +++ & ++ & - & - \\
\hline S. molle & - & - & - & - & + & + & - & + & ++ & - & +++ & +++ & - & - \\
\hline S. lancea & +++ & +++ & +++ & +++ & +++ & +++ & +++ & +++ & ++ & - & ++ & +++ & - & +++ \\
\hline S. leptodictya & +++ & ++ & + & ++ & +++ & ++ & +++ & +++ & +++ & +++ & +++ & +++ & - & ++ \\
\hline S. pyroides & ++ & ++ & - & ++ & ++ & +++ & - & ++ & ++ & + & ++ & +++ & - & ++ \\
\hline S. caffra & +++ & ++ & ++ & ++ & +++ & +++ & + & - & +++ & +++ & +++ & +++ & - & + \\
\hline S. galpinii & +++ & +++ & - & +++ & - & - & - & - & - & + & + & ++ & - & - \\
\hline S. mellifera & +++ & +++ & +++ & +++ & ++ & ++ & ++ & +++ & + & ++ & +++ & +++ & - & ++ \\
\hline T. sericea & + & ++ & +++ & ++ & +++ & +++ & +++ & +++ & ++ & ++ & ++ & +++ & - & +++ \\
\hline V. erioloba & +++ & +++ & +++ & +++ & +++ & +++ & ++ & +++ & + & + & +++ & +++ & - & + \\
\hline V. hebeclada & +++ & + & + & + & - & - & - & - & - & - & ++ & + & - & - \\
\hline V. karroo & +++ & ++ & ++ & ++ & +++ & +++ & ++ & +++ & ++ & ++ & ++ & +++ & - & + \\
\hline $\begin{array}{l}\text { V. nilotica subsp. } \\
\text { Kraussiana }\end{array}$ & + & ++ & + & ++ & +++ & +++ & +++ & +++ & - & ++ & - & + & - & +++ \\
\hline V. robusta & - & ++ & - & ++ & - & ++ & + & ++ & ++ & +++ & ++ & +++ & - & - \\
\hline$V$. tortilis & +++ & ++ & - & ++ & + & ++ & + & + & - & + & ++ & +++ & - & + \\
\hline Z. mucronata & +++ & +++ & - & +++ & - & ++ & - & ++ & + & + & ++ & ++ & - & + \\
\hline
\end{tabular}

+++: highly present; ++: moderately present; +: low; -: absent; M: methanol extract; W: water extract; $\mathrm{AKS}-\mathrm{CH}$ Aeolian Kalahari Sand, Clovelly, and Hutton soil type. 


\subsection{Quantitative Phytochemical Analysis}

Table 3 showed the findings of the effect of species and soil type on the soluble phenols, insoluble tannins, and condensed tannins of browse plants leaves. There were significant differences $(p<0.05)$ observed on the effect of species, soil type, and the interaction between species and soil type on soluble phenol, insoluble tannin, and soluble condensed tannin concentrations of browse leaves found in communal rangelands. In GM-L soil type, $V$. nilotica subsp. Kraussiana and T. sericea had a higher concentration of insoluble tannins $(0.0386 \% \mathrm{DM})$, while in AKS-CH soils, D. cinerea had a higher concentration of insoluble tannins $(0.0453 \% \mathrm{DM})$ when compared to all other species in the same harvesting site. Melia azedarach, D. cinerea, S. mole, S. leptodictya, V. hebeclada, and V. karroo in GM-L soil type had higher insoluble tannin concentration when compared to all other species in the same harvesting site. In both sites, $V$. hebeclada browse leaves had the lowest $(p<0.05)$ insoluble tannin $(0.0041 \%$ DM, GM-L and $0.0064 \%$ DM, AKS-CH soil type) and condensed tannin (0.0137 $\mathrm{AU}_{550} / 200 \mathrm{mg}$, GM-L and $0.0138 \mathrm{AU}_{550} / 200 \mathrm{mg}$, AKS-CH soil type) concentrations. In both sites, $V$. hebeclada browse leaves had the lowest $(p<0.05)$ concentration levels of soluble phenols (Limpopo- $0.0160 \%$ DM) and (North-West-0.0334\% DM). Within GM-L and AKS-CH soil types, $V$. tortilis has shown no significant difference in soluble phenolic content. Again, in the concentration of CTs, Z. mucronate, V. hebeclada, P. africanum, and $T$. sericea did not show any significant differences.

Table 3. Soil type and species effect on soluble phenols (SPhs—\% dry matter), insoluble tannins (ITs$\%$ dry matter), and condensed tannins ( $\mathrm{CTs}-\mathrm{AU}_{550} / 200 \mathrm{mg}$ ) of woody species found in AKS-CH and GM-L soil types.

\begin{tabular}{|c|c|c|c|c|c|c|}
\hline \multirow{2}{*}{ Species } & \multicolumn{2}{|c|}{ Soluble Phenols } & \multicolumn{2}{|c|}{ Insoluble Tannins } & \multicolumn{2}{|c|}{ Condensed Tannins } \\
\hline & GM-L & AKS-CH & GM-L & AKS-CH & GM-L & AKS-CH \\
\hline D. cinerea & $0.1011^{\mathrm{aA}}$ & $0.0969 \mathrm{bB}$ & 0.0259 efB & $0.0453^{\mathrm{aA}}$ & $0.6664^{\mathrm{cdB}}$ & $2.2258^{\mathrm{bA}}$ \\
\hline G. flava & $0.0801 \mathrm{eA}$ & $0.0795^{\mathrm{dA}}$ & $0.0272 \mathrm{deA}$ & $0.0220^{\mathrm{eB}}$ & $0.5141^{\mathrm{eB}}$ & $1.4498^{\mathrm{dA}}$ \\
\hline M. azedarach & $0.0207^{\mathrm{jB}}$ & $0.0830^{\mathrm{cA}}$ & $0.0065^{\mathrm{hB}}$ & $0.0341^{\mathrm{bA}}$ & $0.0114^{\mathrm{iB}}$ & $0.4622 \mathrm{gA}$ \\
\hline P. africanum & $0.0788^{\mathrm{eA}}$ & $0.0758^{\mathrm{eB}}$ & $0.0339 \mathrm{bA}$ & $0.0264^{\mathrm{dB}}$ & $0.8755^{\mathrm{aA}}$ & $0.8746^{\mathrm{fA}}$ \\
\hline S. molle & $0.0377^{\mathrm{iB}}$ & $0.1000^{\mathrm{aA}}$ & $0.0047^{\mathrm{iB}}$ & $0.0184^{\mathrm{fA}}$ & $0.0340^{\mathrm{iB}}$ & $0.2665^{\mathrm{hA}}$ \\
\hline S. leptodictya & $0.0360 \mathrm{iB}$ & 0.0564 ghA & $0.0037^{\mathrm{iB}}$ & $0.0334^{\mathrm{bA}}$ & $0.0243^{\mathrm{iB}}$ & $1.1434^{\mathrm{eA}}$ \\
\hline S. caffra & $0.0659 \mathrm{gA}$ & $0.0514^{\mathrm{iB}}$ & $0.0312^{\mathrm{cA}}$ & $0.0288^{c B}$ & $0.7131^{\mathrm{cB}}$ & $1.6542^{\mathrm{cA}}$ \\
\hline S. galpinii & $0.0869 \mathrm{dA}$ & $0.0385^{\mathrm{jB}}$ & $0.0284 \mathrm{dA}$ & $0.0131 \mathrm{gB}$ & $0.1294^{\mathrm{hB}}$ & $0.1638 \mathrm{jA}$ \\
\hline T. sericea & $0.0908^{\mathrm{cA}}$ & $0.0566 \mathrm{ghB}$ & $0.0386^{\mathrm{aA}}$ & $0.0335 \mathrm{bB}$ & $0.8088^{\mathrm{bA}}$ & $0.8461^{\mathrm{fA}}$ \\
\hline V. hebeclada & $0.0160 \mathrm{kB}$ & $0.0334 \mathrm{kA}$ & $0.0041^{\mathrm{iB}}$ & $0.0064 \mathrm{hA}$ & $0.0137^{\mathrm{iA}}$ & $0.0138^{1 \mathrm{~A}}$ \\
\hline V. karroo & $0.0935^{\mathrm{bA}}$ & $0.0582^{\mathrm{fgB}}$ & $0.0206 \mathrm{gB}$ & $0.0338^{\mathrm{bA}}$ & $0.2879 \mathrm{gB}$ & $2.3270^{\mathrm{aA}}$ \\
\hline V. nilotica subsp. Kraussiana & $0.0897^{\mathrm{cA}}$ & $0.0561 \mathrm{hB}$ & $0.0386^{\mathrm{aA}}$ & $0.0275 \mathrm{cdB}$ & $0.6288^{\mathrm{dA}}$ & $0.5049 \mathrm{gB}$ \\
\hline$V$. tortilis & $0.0598 \mathrm{hA}$ & $0.0598^{f A}$ & $0.0253^{\mathrm{fA}}$ & $0.0230 \mathrm{eB}$ & $0.3530 \mathrm{fA}$ & $0.0737 \mathrm{kB}$ \\
\hline Z. mucronata & $0.0688^{\mathrm{fB}}$ & $0.1009 \mathrm{aA}$ & $0.0335 \mathrm{bA}$ & $0.0196^{\mathrm{fB}}$ & $0.1590 \mathrm{hA}$ & 0.1802 iA \\
\hline SE & \multicolumn{2}{|c|}{0.00066} & \multicolumn{2}{|c|}{0.00056} & \multicolumn{2}{|c|}{0.0165} \\
\hline
\end{tabular}

${ }^{\mathrm{a}-1}$ In a column, means with different lowercase superscripts differ $(p<0.05){ }^{\mathrm{A}-\mathrm{B}}$ in a row, means with different uppercase superscripts differ $(p<0.05)$; GM-L: Glenrosa, Mispah, and Lithosols soil type; SE: standard error.

The results on multivariate tests on the effect of species and soil type on the soluble phenols, insoluble tannins, and condensed tannins of browse plants leaves are shown on Table 4. All of the multivariate tests displayed significant differences $(p<0.001)$ on the effect of species, soil type, and the interaction between species and soil type on soluble phenol, insoluble tannin, and condensed tannin concentration of browse leaves found in communal rangelands. 
Table 4. Multivariate tests ${ }^{\text {a }}$ on soil type and species effect on soluble phenols, insoluble tannins, and condensed tannins of woody species found in AKS-CH and GM-L soil types.

\begin{tabular}{llcccc}
\hline Effect & & Value & F & Error df & $p$-Value \\
\hline \multirow{3}{*}{ Soil type } & Pillai's Trace & 0.992 & $2160.883^{\mathrm{b}}$ & 3.000 & 0.001 \\
& Wilks' Lambda & 0.008 & $2160.883^{\mathrm{b}}$ & 3.000 & 0.001 \\
& Hotelling's Trace & 120.049 & $2160.883^{\mathrm{b}}$ & 3.000 & 0.001 \\
& Roy's Largest Root & 120.049 & $2160.883^{\mathrm{b}}$ & 3.000 & 0.001 \\
Species & Pillai's Trace & 2.978 & 588.200 & 39.000 & 0.001 \\
& Wilks' Lambda & 0.000 & 1091.889 & 39.000 & 0.001 \\
& Hotelling's Trace & 1137.717 & 1536.404 & 39.000 & 0.001 \\
Soil type * species & 696.770 & $3001.471^{\mathrm{c}}$ & 13.000 & 0.001 \\
& Roy's Largest Root & 2.968 & $399.117^{3}$ & 39.000 & 0.001 \\
& Pillai's Trace & 0.000 & $856.022^{2}$ & 39.000 & 0.001 \\
& Wilks' Lambda & 1214.070 & 1639.513 & 39.000 & 0.001 \\
& Hotelling's Trace & 982.735 & $4233.321^{\mathrm{c}}$ & 13.000 & 0.001 \\
\hline
\end{tabular}

${ }^{a}$ Design, soil type + species + soil type ${ }^{*}$ species; ${ }^{\mathrm{b}}$ exact statistic; ${ }^{\mathrm{c}}$ the statistic is an upper bound on $\mathrm{F}$ that yields a lower bound on the significance level; $p$-value: $<0.05$; GM-L: Glenrosa, Mispah, and Lithosols soil type; Error df: degrees of freedom error.

\section{Discussion}

\subsection{Phytochemical Screening of Browse Species}

In almost all cases, the methanol extract showed the presence of a rich variety of secondary metabolites when compared to the distilled water extract. This may be due to the fact that methanol extract tends to dissolve many organic compounds more quickly than in water extract. Again, Paulsamy and Jeeshna [28] highlighted that methanolic solvent tends to draw a higher variety of plant compounds than other solvents. Ghasemzadeh et al. [29] explained that the variation in browse species' nature and polarity level plays a major role in extracting plant secondary metabolites. Similar results were also reported by Shen and Shao [30] and Ingle and Padole [27].

Plant secondary metabolites, which are chemical compounds responsible for biological activities, are commonly found in browse plants [31]. From phytochemical screening in the current study, we observed that the methanol and distilled water extracts from browse species gave positive results in the major phytoconstituent compounds. In this study, Catha edulis leaves from GM-L and S. molle leaves from AKS-CH soil type reported negative in saponin concentration using both methanol and distilled water extracts. The frothing tests were used in the present study to confirm the presence of saponins in the methanol and distilled water extracts on browse species leaves. Okwu [32] indicated that saponins have the distinctive properties of precipitating and coagulating red blood cells and also help in regulating the immune response. These results are in line with those reported by Chaudhary et al. [33] that saponins induce the degradation of cell wall enzymes and the leakage of proteins from the cell.

In this study, flavonoids were found to be moderately present when tested with distilled water extract as compared to those tested with methanol extracts, which were more abundant, and these results are in agreement with those reported by Ajiboye et al. [34] and Senguttuvan et al. [24]. Flavonoids are polyphenolic compounds that are water-soluble and are extensively dispersed in browse plants species, with over 5000 flavonoids discovered [35]. Flavonoids have anti-allergic, anti-inflammatory, tumor inhibitory, antiviral, and anti-cancer properties in addition to antioxidant activities [36,37]. These effects have been associated with health-promoting properties and a wide range of chemical and biological functions, including vasoprotection and free radical scavenging, which can prevent oxidative cell damage [36]. Rauf et al. [38] also reported that flavonoid-rich browse plants are diuretics, whereas others are anti-spasmodic and antibacterial.

Browse plants usually generate phenolics, which are aromatic benzene ring molecules containing one or more hydroxyl groups, mostly to protect plants against stress [39]. Tannin accumulation levels on browse plant species play a critical role in animal health, 
because most plants frequently produce these secondary metabolites either in high or low volume. Hoste et al. [40] indicated that tannins as polyphenolics in natural plants may have detrimental effects on animals consuming high amounts $(>6 \%)$ of tannins in their dietary feed. In this study, tannins and phenols were found negative in $V$. hebeclada from both solvent (methanol and distilled water) extracts. Vachellia hebeclada can be used as a beneficial browse plant for animal consumption due to the fact that it has low levels of tannins and phenols, which are known to be anti-nutritional to animal diet when above $6 \mathrm{~g} / \mathrm{kg}$ of the total intake diet [41]. From the present study, negative results for tannins and phenols were found in most browse leaves from the distilled water extract. Nevertheless, tannins and phenols are not only considered to have detrimental effects, but they also have some beneficial effects that have been documented. Okwa and Josiah [42] reported that tannins have a critical role in promoting healing of wounds and inflamed mucous membranes.

In this study, cardiac glycosides were present, except in V. hebeclada (GM-L and AKS$\mathrm{CH}$ soil types) and M. azederach (GM-L soil type) in both methanol and distilled water extracts. These results may be influenced by browse plant genetic makeup, because polarity did not show any influence in the results reported by Senguttuvan et al. [24] when using methanol and water solvents to test cardiac glycosides. Konstantinou et al. [43] indicated that cardiac glycosides have a direct effect on the heart; they normally aid in restoring a failing heart by maintaining the contraction rate and heart strength. Browse plants rich in glycosides are known to strengthen the immune system, making them useful as dietary supplements. In general, glycosides are present in every woody plant species and play a significant role in therapeutic efficacy. From the present study, terpenoids were found to be present in both methanol and distilled water extracts, except for S. galpinii (GM-L soil type) and $V$. nilotica subsp. krassianna (AKS-CH soil type), which were found to be negative in the distilled water extract. Several authors, such as Wagner and Elmadfa [44] along with Rabi and Bishayee [45], have found that terpenoids have great potential as beneficial remedies for treating and preventing various ailments in both livestock and humans. Again, Wagner and Elmadfa [44] also highlighted that terpenoids have several functions, such as anti-parasitic, antifungal, antimicrobial, and anti-inflammatory properties. Furthermore, terpenoids tend to have insecticidal characteristics, and they can be used as protective chemicals in the storage of agricultural products.

Phlobatannins, in the current study, were found to be absent when using distilled water extract for all woody species leaves in both soil types. These findings may be influenced by the polarity level of water, which was not suitable for drawing phlobatannins in the selected browse leaves. Setchell [46] indicated that phlobatannins in browse plant species have astringent properties, such as anti-inflammation and antiviral as well as antioxidant activities. Moreover, the antimicrobial, antifungal, and anti-parasitic activities of woody species as well as the presence or dispersion of phytochemical compounds appeared to be partly dependent on the host plant species.

\subsection{Phytochemical Quantification of Browse Species}

Secondary plant compounds, which included tannins and phenolics, normally serve important roles in tropical animal productivity, because animals in semi-arid regions rely on woody species as a source of daily feed, and this browse forage tends to accumulate highconcentration levels of phytochemical compounds [41]. In this study, the findings of phytochemical compounds (soluble phenols, insoluble tannins, and condensed tannins) were significantly different among woody species harvested in both sites. Ravhuhali et al. [47] highlighted that woody species found in various locations had a wide range of chemical constituents. Browse species, soil type, and their interaction had an impact on the concentration levels of soluble phenolic (SPhs), insoluble tannins (ITs), and condensed tannins (CTs). The concentration of SPhs on woody species leaves from both soil types was between 0.0160 and $0.1011 \%$ DM, and those woody species in AKS-CH soil type had higher values than those from GM-L soil type. This might be due to different altitudes and soil profiles, because plants growing in the poor soil profiles are known to accumulate 
high levels of phenolics [48], and, in this study, AKS-CH soil type is assumed to have a poor soil profile when compared to GM-L soil type. Reed [49] highlighted that soluble phenols have a moderate impact on ruminant nutrition when compared to tannins. The leaves of $V$. hebeclada had the least soluble phenols in both sites. These results might have been influenced by plant genetic make-up. According to Ibrahim et al. [50], plant genetic make-up has a large impact on concentration levels of phenolics, way more than other abiotic elements (altitude, temperature, light, and soil type) that aid in the secretion of bioactive compounds in woody plants. Schinus molle leaves from AKS-CH soil type had the highest soluble phenolics $(0.1000 \% \mathrm{DM})$, while in GM-L soil type they had the least soluble phenolics $(0.0377 \% \mathrm{DM})$. These results could be due to herbivorous activities, as browse plants trees tend to produce and secrete their defensive chemicals throughout the plants' parts as a form of defense mechanism against herbivorous activities [51]. This might warrant the investigation to assess the most preferred plant by livestock ruminants in the study areas. Mnisi and Mlambo [3] highlighted that dietary intake and digestibility of plant-based feed for livestock can be determined by the number of phenolic compounds constituted in the feed diet.

The concentration of insoluble tannins (ITs) in this study ranged from $0.0037 \% \mathrm{DM}$ (S. leptodictya) to $0.0386 \% \mathrm{DM}$ (T. sericea and V. nilotica subsp. krassianna) in GM-L soil type, and in AKS-CH soil type the levels ranged from $0.0064 \% \mathrm{DM}$ (V. hebeclada) to $0.0453 \% \mathrm{DM}$ (D. cinerea). Within GM-L soil type, S. leptodictya, V. hebeclada, S. molle, and M. azedarach had the lowest insoluble tannins content. With these results, it can be suggested that these browse species can be regarded as a suitable feed source for ruminants due to their lower tannin concentration [52-54].

In this study, condensed tannin (CT) concentration was influenced by species and their environments. Vachellia hebeclada, M. azederaach, S. molle, and S. leptodictya concentration levels of condensed tannins in this study are similar to the findings reported by Mlambo et al. [55] (3-6\%) on the same woody species and this range is regarded as the best concentration level for herbivores. The highest concentration of CTs reported by Mokoboki et al. [11] was in V. karroo leaves, which agrees with the findings of this study. The majority of the selected woody species, regardless of their harvesting sites, had a lower concentration of CTs in this study, which is likely considered to be nutritionally safe. Makkar and Singh [56] indicate that the presence of condensed tannins in large quantities $(>4-9 \%)$ in fiber fractions may influence their digestion kinetic characteristics, causing the link between kinetic measures and fiber composition to be muddled. This is in line with the findings reported by Foo et al. [57], Dube et al. [58], and Mlambo et al. [41], who highlighted that the concentration of CTs accumulated in the animal diet tends to interfere with intake and digestion, while very low concentration has a beneficial effect in ruminants. The variance in condensed tannins content across plant species might be related to genetic make-up, altitude, and herbivory, which results in different response mechanisms to spatial variation $[47,59,60]$. However, to improve the utilization of tanniniferous browse species, tannin-inactivating treatments are required. Various studies have already indicated the use of PEG (polyethylene glycol) and WA (wood ash) to deactivate the protein tannin bonds on various plant parts as a remedy to high-tannin browse plants [61-63].

The results showed that with the use of multivariate analysis tests, a significant effect of soil type, species, and interaction between soil types and browse species on soluble phenols, insoluble tannins, and condensed tannins of woody species. In this study, CTs, ITs, and SPhs concentration was influenced by species and their environments. Indeed, species from different locations tend to have variation in concentration level, and related results were also reported by Schleppi et al. [64] and Suárez et al. [65]. The positive view on the interaction between biotic and abiotic components with living organisms was also highlighted by Hervé et al. [66]. 


\section{Materials and Methods}

\subsection{Description of the Harvesting Sites}

\subsubsection{Limpopo}

The harvesting sites were in the Thulamela and Makhado local municipalities, with a probably high number of livestock, such as goats, sheep, donkeys, and cattle that completely rely on these communal rangelands. The browse tree species were harvested in Lamvi $\left(22^{\circ} 40^{\prime} 21^{\prime \prime} \mathrm{S}, 30^{\circ} 45^{\prime} 26^{\prime \prime} \mathrm{E}\right.$ and $639 \mathrm{~m}$ above sea level) and Mutele $\left(22^{\circ} 28^{\prime} 35^{\prime \prime} \mathrm{S}, 30^{\circ} 50^{\prime} 24^{\prime \prime} \mathrm{E}\right.$ and $339 \mathrm{~m}$ above sea level) in Thulamela municipality and Mpheni $\left(23^{\circ} 08^{\prime} 10^{\prime \prime} \mathrm{S}, 30^{\circ} 03^{\prime} 18^{\prime \prime} \mathrm{E}\right.$ and $808 \mathrm{~m}$ above sea level) village communal area of Makhado municipality in Limpopo. The communal areas have Glenrose, Mispah, and Lithosols (GM-L) soil type, with reddish or brown sandy to loamy soil structure. The vegetation type in the selected communal areas is Soutpansberg Mountain Bushveld and Makuleke Sandy Bushveld vegetations [67]. The study site temperatures range from $13{ }^{\circ} \mathrm{C}$ to $34{ }^{\circ} \mathrm{C}$ and with rainfall range between $200 \mathrm{~mm}$ to $500 \mathrm{~mm}$ annually, respectively.

\subsubsection{North-West Sites}

The North-West province harvesting sites were Mahikeng and Ratlou local municipalities, with high numbers of goats, sheep, and cattle grazing in these communal areas. In Mafikeng, the browse tree leaves were harvested from Six Hundred $\left(25^{\circ} 42^{\prime} 43^{\prime \prime} \mathrm{S}\right.$, $25^{\circ} 37^{\prime} 32^{\prime \prime} \mathrm{E}$ and $1300 \mathrm{~m}$ above sea level) and Tsetse $\left(25^{\circ} 44^{\prime} 07^{\prime \prime} \mathrm{S}, 25^{\circ} 39^{\prime} 40^{\prime \prime} \mathrm{E}\right.$ and $1296 \mathrm{~m}$ above sea level), with both constituted with clay-loamy soil structure, and, meanwhile, Loporung $\left(25^{\circ} 45^{\prime} 37^{\prime \prime} \mathrm{S}, 24^{\circ} 59^{\prime} 54^{\prime \prime} \mathrm{E}\right.$ and $1162 \mathrm{~m}$ above sea level), with red-brown sandy soil structure, is situated in Ratlou municipality in North-West Province, South Africa. These communal areas have Aeolian Kalahari Sand, Clovelly, and Hutton (AKS-CH) soil type, based in Mafikeng Bushveld, Eastern Kalahari Bushveld, and Thornveld vegetation types [67]. These areas receive mean annual rainfall varying from a minimum of $400 \mathrm{~mm}$ to $500 \mathrm{~mm}$. The study sites have winter seasons with sunny dry days and cold nights with an annual average temperature ranging between $2{ }^{\circ} \mathrm{C}$ and $36^{\circ} \mathrm{C}$, with a rainfall ranging from $250 \mathrm{~mm}$ to $450 \mathrm{~mm}$ annually, respectively.

\subsection{Sample Identification and Collection of Browse Plants Leaves}

Randomly fresh browse leaves from five trees per plant species were selected, such as Adansonia digitate, Androstachys johnsonii, Balanites maughamii, Berchemia discolor, Berchemia zeyheri, Bridelia mollis hutch, Carissa edulis, Catha edulis, Colophospermum mopane, Combretum Imberbe, Combretum molle, Combretum collinum, Dalbergia melanoxylon, Dichrostachys cinerea, Diospros lycioides, Diospyros mespiliformis, Euclea divinorum, Flueggea virosa, Grewia flava, Grewia flavescens, Grewia monticola, Grewia occidentalis, Melia azedarach, Peltophorum africanum, Prosopis velutina, Pseudolachnostylis maprouneifolia, Pterocarpus rotundifolius, Schinus molle, Schotia brachypetala, Sclerocarya birrea, Searsia lancea, Searsia leptodictya, Searsia pyroides, Senegalia caffra, Senegalia galpinii, Senegalia mellifera, Senegalia nigrescens, Senegalia polyacantha, Strychnos madagascariensis, Terminalia sericea, Trichilia emetic, Vachellia erioloba, Vachellia hebeclada, Vachellia karroo, Vachellia nilotica, Vachellia nilotica subsp. Kraussiana, Vachellia rechmanniana, Vachellia robusta, Vachellia tortilis, Vachellia tortilis subsp. raddiana, Vangueria infausta, and Ziziphus mucronata. These browse species were harvested from two different (Limpopo and North-West) provinces of South Africa, semi-arid areas under savannah biome. The browse samples were air dried at room temperature for 7 days. All samples were then ground to pass a $0.2 \mathrm{~mm}$ sieve and kept in a plastic container pending chemical analyses. For all procedures, the tests (qualitative and quantitative analyses) were repeated three times for accuracy.

\subsection{Cold Extraction of Secondary Metabolites from Browse Plant Species}

Approximately $10 \mathrm{~g}$ of finely ground browse leaves powder was weighed into a separate $250 \mathrm{~mL}$ conical flasks and then about $100 \mathrm{~mL}$ of each solvent (methanol, distilled water) was added to the flask and sealed with laboratory film (parafilm, Bemis, Brampton, 
ON, Canada). The flasks were kept at normal room temperature for about 7 days, and the flasks were daily shaking for a period of 10-15 min. After 7 days, the extracts were then filtered by using Macherey-Nagel No.1 filter paper under vacuum and then air dried at room temperature in a Petri dish. The weight of each Petri dish was noted prior to drying of the extracts. The weight of the extracts was then calculated from the difference following the procedure demonstrated by Harborne [68].

\subsection{Preliminary Qualitative Phytochemical Screening of Crude Methanolic and Water Extract}

Qualitative phytochemical analyses were carried out using the cold extracts from browse plants following the standard procedure [69] to identify the constituents as demonstrated by Harborne [68], Trease and Evans [70], and Sofowora [71]. The tests for the presence or absence of various plant secondary metabolites (PSM) are summarized below.

\subsubsection{Test for Saponins}

About $0.5 \mathrm{~g}$ of the crude plant extracts was dissolved with distilled water $(10 \mathrm{~mL})$ in a test tube. The suspension was shaken in a test tube for about 10-15 min. A $2 \mathrm{~cm}$ layer of foam was taken as preliminary evidence for saponins [72]. The layer of foam was used to determine the concentration level of saponins, whereby the higher level of foam indicated a higher level of saponins.

\subsubsection{Alkaline Reagent Test (Flavonoids)}

Alkaline reagent test: Exactly $0.5 \mathrm{~g}$ of plant extract was firstly dissolved with solvent (methanol and distilled water) up to $10 \mathrm{~mL}$ in a test tube, and, secondly, an aqueous solution of the extracts was then treated with $10 \%$ ammonium hydroxide solution. The yellow fluorescence indicates a positive test for flavonoids $[73,74]$. The highest level of yellow fluorescence in the test tube symbolized the reflection of high flavonoids.

\subsubsection{Test for Tannins}

About $0.5 \mathrm{mg}$ of crude plant extracts was added to $10 \mathrm{~mL}$ of their freshly prepared solvents (methanol, distilled water) in a test tube and shaken to dissolve. A few (2-4) drops of $0.1 \%$ ferric chloride was added and produced brownish green or a blue-black coloration, which confirms the presence of tannins $[69,74]$. The darkest blue-black color was regarded as a reflection of high concentration of tannins.

\subsubsection{Test for Phenols}

Ferric chloride test: Aqueous plant extracts were treated with 3-4 drops of $0.1 \%$ ferric chloride solution. The formation of a bluish green or black color was confirmed as a positive presence of phenols [75]. The darkest black color was regarded as a reflection of high concentration of phenols.

\subsubsection{Test for Cardiac Glycosides}

Keller-Killani test: About $0.5 \mathrm{~g}$ of crude plant extract was dissolved with $5 \mathrm{~mL}$ of distilled water in the test tube and shaken. Each $5 \mathrm{~mL}$ extract in the test tube was treated with $2 \mathrm{~mL}$ of glacial acetic acid containing a few drops of $0.1 \%$ ferric chloride solution. This was underplayed with $1 \mathrm{~mL}$ of concentrated sulfuric acid $\left(\mathrm{H}_{2} \mathrm{SO}_{4}\right)$ along the side of the test tube. The formation of a brown ring at the interface indicates deoxysugar characteristics of cardenolides, which gives a positive presence of cardenolides. The appearance of a violet-green ring below the brown ring in the acetic acid layer indicates a positive result for cardiac glycosides [76].

\subsubsection{Test for Terpenoids}

Salkowski test: The crude plant extract $(5 \mathrm{~mL})$ was separately shaken with $2 \mathrm{~mL}$ of chloroform and followed by careful addition of concentrated sulfuric acid (2 $\mathrm{mL})$ along the 
test tube to form a layer. A reddish brown coloration of the interface formed, confirming a positive presence of terpenoids $[69,76,77]$.

\subsubsection{Test for Phlobatannins}

About $2 \mathrm{~mL}$ of extract of each plant sample was boiled with $1 \%$ aqueous hydrochloric acid. Appearance of a red precipitate was taken as evidence for the presence of phlobatannins [69].

\subsection{Quantitative Phytochemical Analysis}

The quantitative assay was carried out using the prepared plant extract as described by Makkar [78]. The extraction preparation is described below, and procedures for determination for phenols, tannins, and condensed tannins are summarized below.

\subsubsection{Extract Preparation}

Finely ground browse plant material $(200 \mathrm{mg})$ was weighed into a small $(25 \mathrm{~mL})$ glass beaker; $10 \mathrm{~mL}$ of aqueous acetone $(70 \%)$ was added, and then the glass beaker was suspended in an ultrasonic water bath (Branson 5800) for about $20 \mathrm{~min}$ at room temperature [78]. The content in the glass beaker was then transferred into small centrifuge tubes and subjected to centrifugation for about $10 \mathrm{~min}$ at speed of $3000 \mathrm{rpm}$, with temperature set at $4{ }^{\circ} \mathrm{C}$. After centrifugation, the supernatant was transferred into large test tubes, and the solid particles were left in the small centrifuge tubes. The collected supernatant was kept on ice for further analyses.

\subsubsection{Determination of Total Phenolic Content}

A $0.01 \mathrm{~mL}$ aliquot of tannin-containing extract was pipetted into a test tube. Distilled water $(0.49 \mathrm{~mL})$ and $0.25 \mathrm{~mL}$ of the Folin-Ciocalteu reagent were added to the test tube and then followed by $1.25 \mathrm{~mL}$ of sodium carbonate solution [79]. The test tubes were then vortexed (Lasec Vortex Mixer) and then allowed to stand for $40 \mathrm{~min}$ at room temperature. The absorbance was recorded at $725 \mathrm{~mm}$ wavelength using a spectrophotometer (T60 UVVisible Spectrophotometer, PG Instruments). A standard curve was developed using tannic acid $(0.5 \mathrm{mg} / \mathrm{mL})$, and concentration of tannic acid equivalent in browse leaf samples was predicted from this curve. Concentration of tannic acid in dry matter was expressed as [Tannic acid in grams/Dry matter\%] × 100 .

\subsubsection{Determination of Total Tannins}

Polyvinyl-pyrrolidone (PVP) was used to bind tannins for determining total tannins (TTs), as demonstrated by Makkar [78]. A $100 \mathrm{mg}$ sample of polyvinyl pyrrolidone was weighed into a glass laboratory test tube; $1.0 \mathrm{~mL}$ of distilled water and $1.0 \mathrm{~mL}$ of the tannin-containing extract were added, and this was stored at a temperature of $4{ }^{\circ} \mathrm{C}$ for about $10-15 \mathrm{~min}$. Afterwards, it was centrifuged at $3000 \mathrm{rpm}$ for $10 \mathrm{~min}$. Subsequently, the supernatant was collected with a simple phenolic other than tannins, and the absorbance or UV reading was recorded as mentioned above and expressed as tannin acid equivalent (TAE). Total tannin content was calculated as a difference between simple phenols and total phenol (TP) content in the extract.

\subsubsection{Determination of Condensed Tannins}

The same acetone extract used in the soluble phenolics assay was used to assay for soluble/extractable-condensed tannins (SCT) using the butanol-HCl reagent $(95: 5 v / v)$ [80]. Aqueous acetone extract $(0.5 \mathrm{~mL})$ was pipetted into a glass screw cap test tube and $5 \mathrm{~mL}$ butanol-HCl reagent added. The test tube was closed and then placed on a heating block at $100{ }^{\circ} \mathrm{C}$ for $1 \mathrm{~h}$. Absorbance was measured after the test tubes had cooled to room temperature. The measurements were reported as absorbance units (au) per $200 \mathrm{mg}$ sample at $550 \mathrm{~nm}$ wavelength using the spectrophotometer as prescribed by Makkar [78] (Supplementary Materials). 


\subsection{Statistical Analysis}

Data on quantitative phytochemical composition (insoluble phenols, soluble tannin, and soluble condensed tannin) were analyzed using two-way analysis of variance (ANOVA) that used general linear model (GLM) procedures of SAS 9.3 [81] for a factorial treatment arrangement in a completely randomized design (CRD). Factors such as browse species and soil type were considered in this study. The following general linear model was used:

$$
Y i j k=u+B i+L j+(B \times L) i j+\varepsilon i j k
$$

where $Y_{i j k}$ is the dependent variable, $\mu$ is the overall mean, $B_{i}$ is the effect of browse species, $L j$ is the effect of two different locations (soil type), $(B \times L)_{i j}$ is the interaction effect between browse species and two different locations, and $\varepsilon_{i j k}$ is the random error term associated with observation $i j k$ and assumed to be normally and independently distributed. Where significant variation was detected, multiple comparisons of treatment means were carried out using the probability of difference (pdiff) option of the GLM procedure of SAS [81]. In addition, multivariate analysis was used to test soil type and species effect on soluble phenols, insoluble tannins, and condensed tannins of woody species found in AKS-CH and GM-L soil types.

\section{Conclusions}

The methanol and distilled water extracts of browse species examined in this study contain a variety of phytochemicals that could be responsible for their medicinal, antimicrobial, and antioxidant properties. The most important chemicals are saponins, alkaloids, flavonoids, glycosides, phlobatannins, and terpenoids, which have a metabolic role in biological systems and perform a protective role in livestock. Furthermore, most of the species analyzed had low concentrations of chemical constituents that are essential for maintaining good health. Though there were some discrepancies, the findings suggest that different sites (soil type) and species affected the phytochemical constituent content. To enhance and maximize utilization of these browse plant species, there is a need for various studies to identify all other bioactive compounds constituted in these plant species that may have detrimental effects on animals, e.g., alkaloids, glucosinolates, and terpens. All browse species exposed to animals can be subjected to screening to determine the concentration level of phytochemicals. Multivariate analysis tests revealed a significant effect of both factors and their interaction on soluble phenols, insoluble tannins, and condensed tannins of woody species. To those browse species (S. caffra, V. karroo, and D. cinerea) having high concentration levels of tannins, there is a need to use wood ash or PEG as a remedy to deactivate high tannin protein bonds that reduce the availability of nutrients to the ruminal microbes. The outcomes of this study will provide important information and knowledge on how to improve livestock health and production in semi-arid regions.

Supplementary Materials: The following are available online, Calibration for tannins.

Author Contributions: Conceptualization, H.S.M., H.K.M., K.E.R. and Z.M.; data curation, H.S.M. and K.E.R.; formal analysis, H.S.M., H.K.M., K.E.R. and Z.M.; methodology, H.S.M., H.K.M., K.E.R. and Z.M.; supervision, H.K.M., K.E.R. and Z.M.; validation, H.K.M. and K.E.R.; resources, Z.M.; writing—original draft, H.S.M. and K.E.R.; writing—review and editing, H.S.M., H.K.M., K.E.R. and Z.M. All authors have read and agreed to the published version of the manuscript.

Funding: The authors would like to acknowledge the financial support provided by Department of Agriculture, Forestry, and Fisheries (DAFF) and North-West University.

Institutional Review Board Statement: Not applicable.

Informed Consent Statement: Not applicable.

Data Availability Statement: All data are available upon request. 


\begin{abstract}
Acknowledgments: The authors would like to thank the North-West University School of Agriculture for allowing us to use their experimental farm to analyze our data and providing us with materials for the experiments.
\end{abstract}

Conflicts of Interest: The authors declare no conflict of interest.

Sample Availability: Samples of the compounds are not available from the authors.

\title{
References
}

1. Dambe, L.M.; Mogotsi, K.; Odubeng, M.; Kgosikoma, O.E. Nutritive value of some important indigenous livestock browse species in semi-arid mixed Mopane bushveld, Botswana. Livest. Res. Rural Dev. 2015, 27, 1-10.

2. Aregawi, T.; Melaku, S.; Nigatu, L. Management and utilization of browse species as livestock feed in semi-arid district of North Ethiopia. Livest. Res. Rural Dev. 2008, 20, 1-9.

3. Mnisi, C.M.; Mlambo, V. Influence of harvesting site on chemical composition and potential protein value of Acacia erioloba, A. nilotica and Ziziphus mucronata leaves for ruminants. J. Anim. Physiol. Anim. Nutr. 2016, 101, 994-1003. [CrossRef] [PubMed]

4. Hussain, W.; Haleem, K.S.; Khan, I.; Tauseef, I.; Qayyum, S.; Ahmed, B.; Riaz, M.N. Medicinal plants: A repository of antiviral metabolites. Future Virol. 2017, 12, 299-308. [CrossRef]

5. Lassak, E.V.; McCarthy, T. Australian Medicinal Plants: A Complete Guide to Identification and Usage, 2nd ed.; New Holland Publishers: Chatswood, NSW, Australia, 2011.

6. Amata, I.A.; Lebari, T. Comparative evaluation of the nutrient profile of four selected browse plants in the tropics recommended for uses as non-conventional livestock feeding materials. Afr. J. Biotechnol. 2011, 10, 14230-14233. [CrossRef]

7. Allen, V.G.; Batello, C.; Berretta, E.J.; Hodgson, J.; Kothmann, M.; Li, X.; Mclvor, J.; Milne, J.; Morris, C.; Peeters, A.; et al. An international terminology for grazing lands and grazing animals. Grass Forage Sci. 2011, 66, 2-28. [CrossRef]

8. Ferraz-de-Oliveira, M.I.; Azada, C.; Pinto-Correia, T. Management of Montados and Dehesas for High Nature Value: An interdisciplinary pathway. Agrofor. Syst. 2016, 90, 1-6. [CrossRef]

9. Mokoboki, H.K.; Sebola, A.N.; Ravhuhali, K.E.; Nhlane, L. Chemical composition, in vitro ruminal dry matter degradability and dry matter intake of some selected browse plants. Cogent Food Agric. 2019, 5, 1587811. [CrossRef]

10. Nsubuga, D.; Kalule, D.; Muwanika, V.B.; Masembe, C. Nutritional properties of some browse species used as goat feed in Pastoral dry lands, Uganda. Agrofor. Syst. 2020, 94, 933-940. [CrossRef]

11. Mokoboki, H.K.; Ndlovu, L.R.; Ng'ambi, J.M.; Malatje, M.M.; Nikolova, R.V. Nutritive value of Acacia tree foliages growing in the Limpopo Province of South Africa. S. Afr. J. Anim. Sci. 2005, 35, 221-222. [CrossRef]

12. Ehsen, S.; Qasim, M.; Abideen, Z.; Rizvi, R.F.; Gul, B.; Ansari, R.; Khan, M.A. Secondary metabolites as anti-nutritional factors in locally used halophytic forage/fodder. Pak. J. Bot. 2016, 48, 629-636.

13. Hassan, F.; Arshad, M.A.; Li, M.; Rehman, M.S.; Loor, J.J.; Haung, J. Potential of mulberry leaf biomass and its flavonoids to improve production and health in ruminants: Mechanistic insights and prospects. Animals 2020, 10, 2076. [CrossRef] [PubMed]

14. Mazid, M.; Khan, T.A.; Mohammed, F. Role of secondary metabolites in defense mechanisms of plants. Biol. Med. 2011, 3, 232-249.

15. Liu, B.; Zhong, F.; Yokoyama, W.; Huang, D.; Zhu, S.; Li, Y. Interactions in starch co-gelatinized with phenolic compound systems: Effect of complexity of phenolic compounds and amylose content of starch. Carbohydr. Polym. 2020, 247, 116667. [CrossRef]

16. Mueller-Harvey, I. Unraveling the conundrum of tannins in animal nutrition and health. J. Sci. Food Agric. 2006, 86, 2010-2037. [CrossRef]

17. Corso, M.; Perreau, F.; Mouille, G.; Lepiniec, L. Specialized phenolic compounds in seeds: Structures, functions, and regulations. Plant Sci. 2020, 296, 110471. [CrossRef]

18. Katalinic, V.; Milos, M.; Kulisi, T.; Juki, M. Screening of 70 medicinal plant extracts for antioxidant capacity and total phenols. Food Chem. 2004, 94, 50-57. [CrossRef]

19. Sattar, T. Would Some Herbal Teas Play a Medicating Role for Certain Diseases? Curr. Nutr. Food Sci. 2021, 17, 176-188. [CrossRef]

20. Junsathian, P.; Yordtong, K.; Corpuz, H.; Katayama, S.; Nakamura, S.; Rawdkuen, S. Biological and neuroprotective activity of Thai edible plant extracts. Ind. Crops Prod. 2018, 124, 548-554. [CrossRef]

21. Salem, M.A.; Perez de Souza, L.; Serag, A.; Fernie, A.R.; Farag, M.A.; Ezzat, S.M.; Alseekh, S. Metabolomics in the context of plant natural products research: From sample preparation to metabolite analysis. Metabolites 2020, 10, 37. [CrossRef]

22. Verpoorte, R.; Choi, Y.H.; Kim, H.K. NMR-based metabolomics at work in phytochemistry. Phytochem. Rev. 2007, 6, 3-14. [CrossRef]

23. Ismail, A.M.; Mohamed, E.A.; Marghany, M.R.; Abdel-Motaal, F.F.; Abdel-Farid, I.B.; El-Sayed, M.A. Preliminary phytochemical screening, plant growth inhibition and antimicrobial activity studies of Faidherbia albida legume extracts. J. Saudi Soc. Agric. Sci. 2016, 15, 112-117. [CrossRef]

24. Senguttuvan, J.; Paulsamy, S.; Karthika, K. Phytochemical analysis and evaluation of leaf and root parts of the medicinal herb, Hypochaeris radicata L. for in vitro antioxidant activities. Asian Pac. J. Trop. Biomed. 2014, 4, 359-367. [CrossRef] [PubMed]

25. Yadav, M.; Chatterji, S.; Gupta, S.K.; Watal, G. Preliminary phytochemical screening of six medicinal plants used in traditional medicine. Int. J. Pharm. Pharm. Sci. 2014, 6, 539-542. 
26. Gul, R.; Jan, S.U.; Faridullah, S.; Sherani, S.; Jahan, N. Preliminary phytochemical screening, quantitative analysis of alkaloids, and antioxidant activity of crude plant extracts from Ephedra intermedia indigenous to Balochistan. Sci. World J. 2017, 2017, 5873648. [CrossRef] [PubMed]

27. Ingle, K.P.; Padole, D.A. Phosphate solubilizing microbes: An overview. Int. J. Curr. Microbiol. Appl. Sci. 2017, 6, 844-852. [CrossRef]

28. Paulsamy, S.; Jeeshna, M.V. Preliminary phytochemistry and antimicrobial studies of an endangered madicinal herb Exacum bicolor Roxb. Res. J. Pharm. Biol. Chem. Sci. 2011, 2, 447-457.

29. Ghasemzadeh, A.; Jaafar, H.Z.; Rahmat, A. Effects of solvent type on phenolics and flavonoids content and antioxidant activities in two varieties of young ginger (Zingiber officinale Roscoe) extracts. J. Med. Plant Res. 2011, 5, 1147-1154.

30. Shen, J.; Shao, X. A comparison of accelerated solvent extraction, Soxhlet extraction, and ultrasonic-assisted extraction for analysis of terpenoids and sterols in tobacco. Anal. Bioanal. Chem. 2005, 383, 1003-1008. [CrossRef]

31. Yang, L.; Wen, K.S.; Ruan, X.; Zhao, Y.X.; Wei, F.; Wang, Q. Response of plant secondary metabolites to environmental factors. Molecules 2018, 23, 762. [CrossRef]

32. Okwu, D.E. Phytochemicals and vitamin content of indigenous spices of south eastern Nigeria. J. Sustain. Agric. Environ. 2004, $6,30-37$.

33. Chaudhary, M.; Bhagyawant, S.S.; Srivastava, N. Effects of Prednisolone Derivative and Panaxydol: Biosurfactants on Cell Wall Integrity of Acne-Causing Resistant Bacteria. Cell Biochem. Biophys. 2021, 1-15. [CrossRef]

34. Ajiboye, T.O.; Ahmad, F.M.; Daisi, A.O.; Yahaya, A.A.; Ibitoye, O.B.; Muritala, H.F.; Sunmonu, T.O. Hepatoprotective potential of Phyllanthus muellarianus leaf extract: Studies on hepatic, oxidative stress and inflammatory biomarkers. Pharm. Biol. 2017, 55, 1662-1670. [CrossRef]

35. Harborne, J.B.; Williams, C.A. Advance in flavonoid research since 1992. Phytochemistry 2010, 55, 481-504. [CrossRef]

36. Xiao, L.P.; Sun, Z.J.; Shi, Z.J.; Xu, F.; Sun, R.C. Impact of hot compressed water pretreatment on the structural changes of woody biomass for bioethanol production. BioResources 2011, 6, 1576-1598.

37. Mbikay, M. Therapeutic potential of Moringa oleifera leaves in chronic hyperglycemia and dyslipidemia: A review. Front. Pharmacol. 2012, 3, 24. [CrossRef]

38. Rauf, A.; Akram, M.; Semwal, P.; Mujawah, A.A.; Muhammad, N.; Riaz, Z.; Munir, N.; Piotrovsky, D.; Vdovina, I.; Bouyahya, A.; et al. Antispasmodic Potential of Medicinal Plants: A Comprehensive Review. Oxid. Med. Cell. Longev. 2021, $2021,4889719$. [CrossRef]

39. Obied, H.K. Biography of biophenols: Past, present and future. Funct. Foods Health Dis. 2013, 3, 230-241. [CrossRef]

40. Hoste, H.; Jackson, F.; Athanasiadou, S.; Thamsborg, S.M.; Hoskin, S.O. The effects of tannin-rich plants on parasitic nematodes in ruminants. Trends Parasitol. 2006, 22, 253-261. [CrossRef]

41. Mlambo, V.; Marume, U.; Gajana, C.S. Utility of the browser's behavioural and physiological strategies in coping with dietary tannins: Are exogenous tannin-inactivating treatments necessary? S. Afr. J. Anim. Sci. 2015, 45, 441-451. [CrossRef]

42. Okwu, D.E.; Josiah, C. Evaluation of the chemical composition of two Nigerian medicinal plants. Afr. J. Biotechnol. 2006, $5,357-361$

43. Konstantinou, D.M.; Karvounis, H.; Giannakoulas, G. Digoxin in heart failure with a reduced ejection fraction: A risk factor or a risk marker? Cardiology 2016, 134, 311-319. [CrossRef] [PubMed]

44. Wagner, K.H.; Elmadfa, I. Biological relevance of terpenoids: Overview focusing on mono-di and tetraterpenes. Ann. Nutr. Metab. 2003, 47, 95-106. [CrossRef] [PubMed]

45. Rabi, T.; Bishayee, A. Terpenoids and breast cancer chemoprevention. Breast Cancer Res. Treat. 2009, 115, 223-239. [CrossRef]

46. Setchell, K.D.; Cassidy, A. Dietary isoflavones: Biological effects and relevance to human health. J. Nutr. 1999, $29,758-767$. [CrossRef]

47. Ravhuhali, K.E.; Mlambo, V.; Beyene, T.S.; Palamuleni, L.G. Effects of soil type on density of trees and nutritive value of tree leaves in selected communal areas of South Africa. S. Afr. J. Anim. Sci. 2020, 50, 88-98. [CrossRef]

48. D'mello, J.P.F. Anti-nutritional factors and mycotoxins. In Farm Animal Metabolism and Nutrition; CABI Publishing: Wallingford, UK, 2000; p. 383.

49. Reed, J.D. Nutritional toxicology of tannins and related polyphenols in forage legumes. J. Anim. Sci. 1995, 73, 1516-1528. [CrossRef]

50. Ibrahim, M.N.M.; Tamminga, S.; Zemmelink, G. Nutritive value of some commonly available ruminant feeds in Sri Lanka. In Proceedings of the Seventh Annual Workshop of the Australian-Asian Fibrous Agricultural, Chang Mai University, Chiang Mai, Thailand, 2-4 June 1988.

51. Gowda, J.H. Physical and chemical responses of juvenile Acacia tortilis trees to browsing Experimental evidence. Funct. Ecol. 1997, 11, 106-111. [CrossRef]

52. Mahipala, M.K.; Krebs, G.L.; McCafferty, P.; Gunaratne, L.H.P. Chemical composition, biological effects of tannin and in vitro nutritive value of selected browse species grown in the West Australian Mediterranean environment. Anim. Feed Sci. Technol. 2009, 153, 203-215. [CrossRef]

53. Waghorn, G.C.; McNabb, W.C. Consequences of Plant Phenolic Compounds for Productivity and Health of Ruminants; Cambridge University Press: Cambridge, UK, 2003; Volume 62, pp. 383-392.

54. Aganga, A.A.; Tshwenyane, S.O. Feeding values and anti-nutritive factors of forage tree legumes. Pak. J. Nutr. 2003, 2, $170-177$. 
55. Mlambo, V.; Mould, F.L.; Smith, T.; Owen, E.; Sikosana, J.L.N.; Mueller-Harvey, I. In vitro biological activity of tannins from Acacia and other tree fruits: Correlations with colorimetric and gravimetric phenolic assays. S. Afr. J. Anim. Sci. 2009, 39, 131-143. [CrossRef]

56. Makkar, H.P.S.; Singh, B. Distribution of condensed tannin (proanthocyanidins) in various fractions in young and mature leaves of some oak species. Anim. Feed Sci. Technol. 1999, 32, 253-260. [CrossRef]

57. Foo, L.Y.; Newman, R.; Waghorn, G.C.; McNabb, W.A.; Ulyatt, M.J. Proanthocyanidins from Lotus corniculatus. Phytochemistry 1996, 41, 617-624. [CrossRef]

58. Dube, J.S.; Reed, J.D.; Ndlovu, L.R. Proanthocyanidins and other phenolics in Acacia leaves of Southern Africa. Anim. Feed Sci. Technol. 2001, 91, 59-67. [CrossRef]

59. Kraus, T.E.C.; Yu, Z.; Preston, C.M.; Dahlgren, R.A.; Zasoski, R.J.Z. Linking chemical reactivity and protein precipitation to structural characteristics of foliar tannins. J. Chem. Ecol. 2003, 29, 703-730. [CrossRef]

60. Petrussa, E.; Braidot, E.; Zancani, M.; Peresson, C.; Bertolini, A.; Patui, S.; Vianello, A. Plant flavonoids-biosynthesis, transport and involvement in stress responses. Int. J. Mol. Sci. 2013, 14, 14950-14973. [CrossRef]

61. Mukuru, S.Z.; Butler, L.G.; Rogler, J.C.; Kireis, A.W.; Ejeta, G.; Axtell, J.D.; Mertz, E.T. Traditional processing of high tannin sorghum grain in Uganda and its effect on tannin, protein in digestibility and rat growth. J. Sci. Food Agric. 1992, 40, 1172-1175. [CrossRef]

62. Barry, T.N.; McNeill, D.M.; McNabb, W.C. Plant secondary compounds; their impact on forage nutritive value and upon animal production. In Proceedings of the 19th International Grassland Congress, Sao Paulo, Brazil, 11-21 February 2001; pp. 445-452.

63. Smith, T.; Mlambo, V.; Sikosana, J.L.N.; Maphosa, V.; Mueller-Harvey, I.; Owen, E. Dichrostachys cinerea and Acacia nilotica fruits as dry season feed supplements for goats in a semi-arid environment: Summary of a DFID funded project in Zimbabwe. Anim. Feed Sci. Technol. 2005, 122, 149-157. [CrossRef]

64. Schleppi, P.; Tobler, L.; Bucher, J.B.; Wyttenbach, A. Multivariate interpretation of the foliar chemical composition of Norway spruce (Picea abies). Plant Soil 2000, 219, 251-262. [CrossRef]

65. Suárez, M.H.; Galdón, B.R.; Rodríguez, E.R.; Romero, C.D. Influence of agronomic variables on quality of tomato fruits. J. Agric. Sci. 2011, 2, 424. [CrossRef]

66. Hervé, M.R.; Nicolè, F.; Lê Cao, K.A. Multivariate analysis of multiple datasets: A practical guide for chemical ecology. J. Chem. Ecol. 2018, 44, 215-234. [CrossRef] [PubMed]

67. Mucina, L.; Rutherford, M.C. The Vegetation of South Africa, Lesotho and Swaziland; South African National Biodiversity Institute: Pretoria, South Africa, 2006.

68. Harborne, J.B. Phytochemical Methods: A Guide to Modern Techniques of Plant Analysis; Chapman A \& Hall: London, UK, 1973; pp. 49-188.

69. Harborne, J.B. Phytochemical Methods: A Guide to Modern Techniques of Plant Analysis, 3rd ed.; Springer: Dordrecht, The Netherlands, 1998.

70. Trease, G.E.; Evans, W.C. A Text-Book of Pharmacognosy. Bailliere Tindall Ltd.: London, UK, 1989; p. 53.

71. Sofowora, A. Medicinal Plants and Traditional Medicines in Africa. Spectrum Books Ltd.: Ibadan, Nigeria, 1993; pp. 289-300.

72. Kokate, A. Phytochemical Methods. Phytotherapy 1999, 78, 126-129.

73. Mace, G.S.L. Anaerobic bacteriology for clinical laboratories. Pharmacognosy 1963, 23, 89-91.

74. Kardong, D.; Upadhyaya, S.; Saikia, L.R. Screening of phytochemicals, antioxidant and antibacterial activity of crude extract of Pteridium aquilinum Kuhn. J. Pharm. Res. 2013, 6, 179-182. [CrossRef]

75. Tiwari, P.; Kumar, B.; Kaur, M.; Kaur, G.; Kaur, H. Phytochemical screening and extraction: A review. Int. Pharm. Sci. 2011, 1, 98-106.

76. Obianime, A.W.; Uche, F.I. The phytochemical screening and effects of methanolic extract of Phyllanthus amarus leaf on the biochemical parameters of male guinea pigs. J. Appl. Sci. Environ. Manag. 2008, 12, 73-77.

77. Iqbal, E.; Salim, K.A.; Lim, L.B. Phytochemical screening, total phenolics and antioxidant activities of bark and leaf extracts of Goniothalamus velutinus (Airy Shaw) from Brunei Darussalam. J. King Saud Univ. Sci. 2015, 27, 224-232. [CrossRef]

78. Makkar, H.P.S. Effects and fate of tannins in ruminant animals, adaptation to tannins, and strategies to overcome detrimental effects of feeding tannin-rich feeds. Small Rumin. Res. 2003, 49, 241-256. [CrossRef]

79. Waterman, P.G.; Mole, S. Analysis of Phenolics Plant Metabolites; Blackwell: Oxford, UK, 1994.

80. Porter, L.J.; Horstich, L.N.; Chan, B.G. The conversion of procyanidins and prodelphinidins to cyaniding and delphinidin. Phytochemistry 1986, 1, 223-230.

81. SAS. Statistical Analysis System. User Guide: Statistics, Version 9.3; SAS Institute: Cary, NC, USA, 2010. 